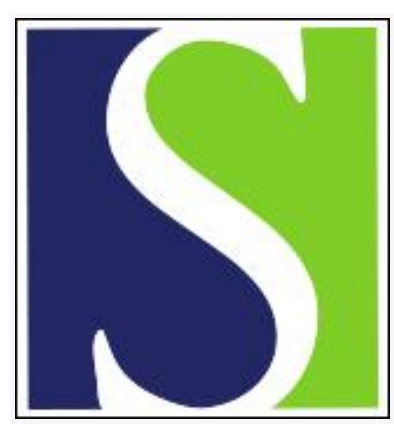

Scand J Work Environ Health 1993;19(1):21-28

https://doi.org/10.5271/sjweh.1508

Issue date: 01 Feb 1993

Measuring work organization exposure over the life course with a job-exposure matrix.

by Johnson JV, Stewart WF

Affiliation: Division of Behavioral Sciences and Health Education, Johns Hopkins School of Hygiene and Public Health, Baltimore, Maryland.

The following articles refer to this text: 2013;39(4):351-360;

2019;45(4):421-422; 2020;46(3):259-267; 2020;46(5):498-507;

2020;46(5):542-551; 2022;48(6):435-445

This article in PubMed: www.ncbi.nlm.nih.gov/pubmed/8465168

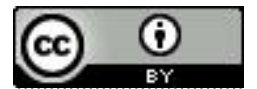




\title{
Measuring work organization exposure over the life course with a job-exposure matrix
}

\author{
by Jeffrey $\mathrm{V}$ Johnson, $\mathrm{PhD},{ }^{1}$ Walter $\mathrm{F}$ Stewart, $\mathrm{PhD}^{2}$
}

\begin{abstract}
JOHNSON JV, STEWART WF. Measuring work organization exposure over the life course with a job-exposure matrix. Scand J Work Environ Health 1993;19:21-8. In most epidemiologic studies of occupational stress, work exposure is measured at only one point in time. This article presents a methodology for measuring the intensity and duration of work organization exposure over a lifetime. A job-exposure matrix for work organization was developed from data on a random sample $(\mathrm{N}=12084)$ of the Swedish labor force. The matrix consisted of mean exposure estimates for work control, social support, psychological and physical job demands, and job hazards for 261 occupations. Several validations of the matrix were undertaken. The matrix scores were found to be significantly correlated with individual self-report scores, and a similar increase in chronic disease prevalence with decreasing work control was found for both the matrix and the individual scores. The matrix was applied to occupational history data to construct lifetime exposure profiles. Potential problems in using attribution systems for exposure assessment are discussed.
\end{abstract}

Key terms: epidemiology, exposure assessment, job control, occupational health, psychological job strain, longitudinal, research methods, social support, work environment, work stress.

Increasing evidence suggests that exposure to adverse work organization characteristics (such as high performance demands coupled with low levels of work control and social support) place individuals at increased risk of stress and chronic illnesses $(1-12)$. A number of major methodological challenges remain, however, before a clear causal association between work organization and physical illness can be established $(5,13-17)$. One such challenge involves the question of how exposure to work organization is conceptualized and measured.

In population-based epidemiologic studies, work characteristics have been measured in two ways. Questionnaire responses of large samples about their work content have been used to characterize the exposure of individuals at the time of the interview (5, $7,11,12$ ), or, alternatively, national survey registers have been used to develop attribution systems by aggregating survey responses of individuals to arrive at occupationally representative scores for work environment characteristics $(18-21)$. These occupational scores are then attributed to subjects (frequent-

1 Division of Behavioral Sciences and Health Education, The Johns Hopkins School of Hygiene and Public Health, Baltimore, Maryland, United States.

2 Department of Epidemiology, The Johns Hopkins School of Hygiene and Public Health, Baltimore, Maryland, United States.

Reprint requests to: Dr JV Johnson, Division of Behavioral Sciences, Johns Hopkins School of Public Health, 624 North Broadway, Baltimore, MD 21205, USA. ly in another data set) on the basis of the job held at a given point in time $(19,20,22,23)$. Both of these measurement systems share methodological weaknesses in that the exposure status is usually assessed cross-sectionally and is based solely on the job held at the time of interview. Indeed, with a few exceptions $(5,16,24,25)$, the idea of exposure as a timedependent process exerting an incremental effect on the risk of disease has not been thoroughly conceptualized or investigated in the occupational stress field. In earlier population-based studies it was assumed that work organization either exerts an acute effect on disease risk or that the exposures for all past occupations were identical to those of the last occupation. The first assumption is inconsistent with recent evidence that cumulative exposure to adverse work organization is associated with an excess risk of chronic disease $(7-12,18-20,22,23)$. Given the propensity for job change and career mobility in modern society, the second assumption is not reasonable. Moreover, in such studies the potential effects of prior exposure such as that motivating an individual to change occupations and the time-dependent relationship between exposure and disease risk cannot be evaluated.

This paper presents a procedure for assessing exposure to three psychosocial and two physical work organization characteristics retrospectively. Using methods developed in occupational epidemiology (26), we have developed a job-exposure matrix for work organization (ie, a work organization matrix) to assign exposure scores retrospectively to occupational title groups and create an individual worklife time-exposure profile. 


\section{Material and methods}

In occupational studies of chemical agents a detailed profile of exposure to a specific agent is often lacking, and, for diseases with long incubation and latency periods, data are typically insufficient to define exposure quantitatively on an individual basis. Exact approximations of a worker's exposure profile is only possible when the induction and latency periods are short or when monitoring data have been systematically collected over the period of employment of the study cohort. These challenges have motivated the use of surrogates of the subject's specific exposure profile, for example, the job-exposure matrix (26-28), which is used to approximate exposure intensities over time. The simplest type of jobexposure matrix consists of occupational groups or some other means of defining homogeneous exposure clusters $(27-28)$. Other dimensions are added to the matrix when exposure variation exists within occupations. We have applied this general approach to the construction of a work organization matrix.

\section{Sample}

The 1977 and 1979 years of the Survey of Living Conditions made by Statistics Sweden were used to construct the work organization matrix. The response rates were $81 \%$ in 1977 and $89 \%$ in 1979 . The survey is performed annually and consists of systematic random samples of the entire Swedish population from the ages of 16 to 74 years. These two years were chosen because they contained the most extensive information on the work environment. The work organization matrix was based on the responses of 12084 employed Swedish citizens between the ages of 25 and 74 years. Altogether 5658 subjects (46.8\%) were women and $6426(53.2 \%)$ were men. NonSwedish citizens were excluded because of the likelihood that a significant portion of their work history had occurred in their native country. A 25 -yearold age entry criterion was used because no data on occupational history were available before this age.

\section{Measurement of work characteristics}

The indicators for the work environment characteristics used in this study have been shown to predict cardiovascular disease $(11-12)$ and psychosomatic strain. The questionnaire items have been published elsewhere $(12,25,29-31)$, and the reliability and validity of the indicators have been discussed in several publications $(7,11,25,29-31)$. All of the scales were multiplicatively transformed so that the scale scores ranged from 0 to 10 .

The work-control scale is a 12-item indicator measuring decision authority and skill discretion on the job with a mean of 4.89 and a standard deviation of 2.01. Cronbach's alpha is 0.75 for this scale.

The work social-support index is a four-item measure of the availability of social interaction in the workplace and with co-workers. The mean of the index is 8.67 , and the standard deviation is 2.14 . No alpha has been computed for this index since it measures interaction opportunities rather than a latent construct.

The psychological job-demand indicator is a twoitem scale that measures time pressure and psychological demand. It has a mean of 4.70 , a standard deviation of 3.94, and a reliability coefficient of 0.60 .

The physical job-demand indicator consists of five items that measure the physical burden of the job. The mean of the scale is 4.70 , its standard deviation is 3.94, and its Cronbach's alpha is 0.73 .

The hazardous exposure scale is made up of seven items that address a series of exposure characteristics that are potentially hazardous. It has a mean of 2.65 , a standard deviation of 2.23 , and a Cronbach's alpha of 0.71 .

\section{Statistical methods}

In the interview the subjects were asked to recall their complete work history and the duration of time each job was held. Information on only the current occupation was used to construct the work organization matrix. The Nordic version of the three-digit International Standard Classification of Occupations was used to form 261 occupational title groups (32). Exposure scores for each job characteristic were estimated by gender, occupation, age (two categories: $25-44$ and $\geq 45$ years), and the duration of time in the specific occupation (three categories: $1-5,6$ 19 , and $\geq 20$ years). Separate job-exposure matrices were developed for the men and women on the basis of the previous work of Hall (30), who reported that the majority of Swedish workers are employed in jobs that are highly gender segregated. In addition, Hall reported that there are significant gender differences in the level of work control for men and women holding the same job (32). These findings suggest that men and women in the Swedish labor force, and even in the same occupation, can be exposed to differing levels of work organization characteristics (33).

In its most stratified form the work organization matrix distinguishes between chronological age and duration of employment within a specific occupation. Previous job-characteristic attribution systems have stratified or adjusted for age (20-21). Since age is more readily available than duration of employment, and in order to increase the general utility of the work organization matrix for other investigators, genderspecific occupational scores were stratified by age alone (the duration categories being collapsed). Gender-specific occupational means (collapsed across age and duration of employment) have also been included in the work organization matrix. The decision to use one form or the other is up to the investigator and would depend on his or her specific research 
question and the availability of information related to age and duration of employment.

Although age is often used as a proxy for duration of employment, the introduction of a separate time dimension strengthens the accuracy of the jobcharacteristic estimates in those situations when age and duration of employment are not the same. At an individual level, to the extent that a worker moves in and out of the labor force or undergoes career mobility, chronological age will not adequately measure duration of employment. This situation is the truest for women, who often leave the labor force during child-rearing years, to return again later in life. A woman, on reentry into the labor force, must often literally "begin at the beginning" - even though she may be older. We have found that in certain jobs predominately performed by women (such as typist, secretary, cashier, and bookkeeper) women who start working in their forties report lower levels of work control than do women who start these jobs in their twenties.

In an analysis of variance of both the individual scores and the matrix-attributed scores age, duration of employment, and the age-duration interaction were found to be statistically significant.

The Statistical Analysis System (34) was used to generate the input data set for the matrix. This procedure was performed separately for the men and women, and it created occupational means and variances for the five work characteristics. According to the criterion established in earlier occupational attribution systems, a minimum sample size of four was required for a gender, occupation, age, and duration of work specific category to estimate directly the mean score and standard deviation $(20-21)$. If the sample size was less than four, then we estimated the cell-specific mean by borrowing data from the nearest neighbor cells until the sample size for the estimate was itself greater than or equal to four. The order of borrowing was gender-specific, occurred mainly within the three-digit occupational code, and was decided on the basis of proximity of an age- and duration-specific cell to the cell of interest.

The coefficient of variation (CV) (standard deviation/mean) was used to examine the relative variability of the estimates of the work organization matrix for the work-control variable as a function of the sample size of the cell. The CV values generally ranged from 0 to 0.85 for both the men and the women, the majority of estimates ranging from 0.10 to 0.60 . The average $\mathrm{CV}$ was approximately 0.35 , irrespective of cell size. Though the CV range was somewhat broader for the smaller cell sizes, there was little indication of a meaningful association between cell size and the magnitude of the CV. We would also note that when the work organization matrix was applied to individuals in the study sample, only $4 \%$ of the men and $2 \%$ of the women received estimates derived from cell sizes of four. Altogether $85 \%$ of the men and $90 \%$ of the women re- ceived estimates derived from a cell size of eight or more.

All of the technical and other details regarding the work organization matrix have been published as a research monograph that is available upon request $(25) .^{3}$

\section{Results}

\section{Proportion of variance explained by the work organization matrix}

The proportion of the population variance in a work characteristic explained by the work organization matrix was assessed through a comparison of attributed and self-report scores associated with the occupation held at the time of the interview according to the methods developed by Schwartz et al (21). The proportion of the total sample variance explained by the work organization matrix was estimated from the correlation of the attributed score specific for gender, occupation, age, and duration of employment with the self-report score. The Cronbach's alpha reliability coefficients reported in the Measurement of Work Characteristics section were used to estimate the upper bound of variance that can be reliably measured for each scale (21). The ratio of variance estimated from the attributed scores to the total reliable variance, estimated by Cronbach's alpha, was derived for each scale.

Although the proportion of variance explained by the work organization matrix (table 1) was greater for the men than for the women, the pattern was similar for both genders. Of the five variables, the attributed score for physical job demands accounted for the greatest proportion of explained variance for both genders, and the largest ratio of explained to reliable variance (ie, $73 \%$ for the men and $49.3 \%$ for the women). The work-control and job-hazard indices also explained a meaningful proportion of the individual score variance for the men and women. The ratio of explained to reliable variance ranged from 32.4 to $63.5 \%$ for the women and men, respectively. The attributed score for psychological job demands explained the least reliable variance $(29.3 \%$ for the men and $24 \%$ for the women). This finding was not unexpected, given that the few items comprising this index were more likely to reflect the individual perception of work conditions at the time of the interview in contrast to the structural characteristics of the job. As such, there is likely to be greater heterogeneity of exposure within any one occupational category. The social support indicator also explained only $25 \%$ of the sample variance. This situation may be due to the considerable variation in

\footnotetext{
The complete job-exposure matrix (25) is available in Stress Research Reports, number 221, from the Swedish National Institute for Psychosocial Factors and Health, Box 60210, S-104 01 Stockholm, Sweden.
} 
Table 1. Proportion of sample variance and total reliable variance explained by the work organization matrix for five work characteristics among Swedish men $(N=5312)$ and women $(N=5069)$. ( $R^{2}=$ explained variance)

\begin{tabular}{|c|c|c|c|c|}
\hline \multirow[b]{2}{*}{ Job variable } & \multicolumn{2}{|r|}{ Men } & \multicolumn{2}{|c|}{ Women } \\
\hline & $\% \mathrm{R}^{2}$ & $\begin{array}{l}\text { Ratio of } \mathrm{R}^{2} \text { to } \\
\text { total reliable variance }\end{array}$ & $\% \mathrm{R}^{2}$ & $\begin{array}{l}\text { Ratio of } \mathrm{R}^{2} \text { to } \\
\text { total reliable variance }\end{array}$ \\
\hline $\begin{array}{l}\text { Work control } \\
\text { Social support } \\
\text { Psychological job demands } \\
\text { Physical job demands } \\
\text { Job hazards }\end{array}$ & $\begin{array}{l}47.6 \\
25.0 \\
17.6 \\
53.3 \\
43.6\end{array}$ & $\begin{array}{l}63.5 \\
\cdot \\
29.3 \\
73.0 \\
61.4\end{array}$ & $\begin{array}{l}34.8 \\
22.1 \\
14.4 \\
36.0 \\
23.0\end{array}$ & $\begin{array}{l}46.4 \\
24.0 \\
49.3 \\
32.4\end{array}$ \\
\hline
\end{tabular}

a Total reliable variance determined by Cronbach's alpha reliability coefficient.

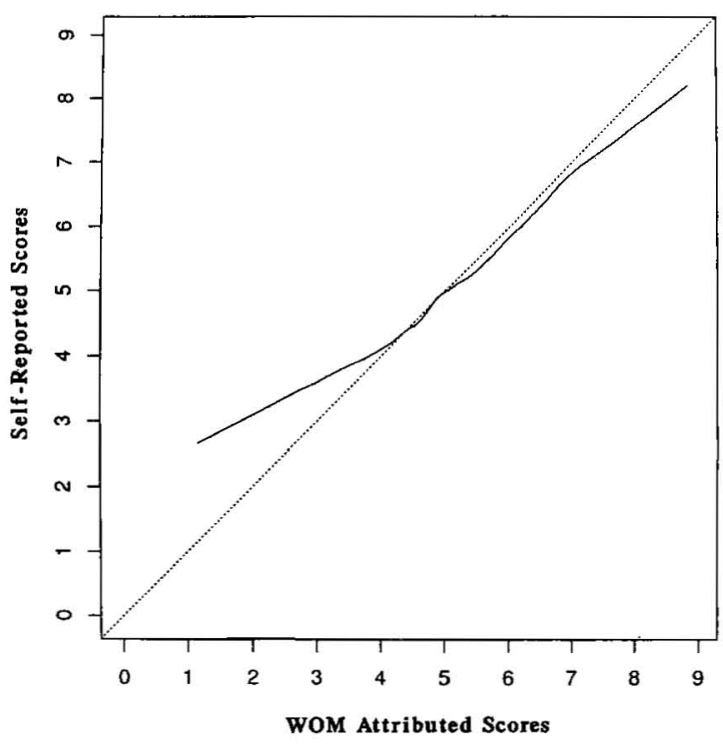

Figure 1. Regression of the individual self-report scores for work control on the attributed scores for work control of the work organization matrix (WOM) among 5312 employed Swedish men. The broken line represents the best fit of the self-report and attributed scores and the unbroken line is the observed regression line.

social support opportunities that occur within occupations (ie, variance that is not captured by the work organization matrix indicator). By contrast, the items comprising the work-control and physical-demand indicators focused on characteristics that were more likely to vary markedly between occupations. Similar findings have been noted by Schwartz et al (21) regarding the psychological-demand and work-control indicators.

It is possible that a proportion of the variance in the individual self-report scores explained by the scores of the work organization matrix may be due to the fact that the scores were initially derived from these same individual self-reports. In order to test whether this issue of circularity accounted for the observed associations, we applied the work organization matrix to a different nationally representative, random sample $(\mathrm{N}=6138)$ that was collected by Statistics Sweden in 1980 and included a physical job- demand indicator. This check yielded a correlation of 0.61 for the men and 0.47 for the women between the scores of the work organization matrix and the individual self reports for physical job demands. Although the magnitudes of these associations are somewhat less than those previously obtained, they are sufficiently strong to suggest that circularity does not account for the preponderance of the associations reported in this article.

The attributed score for work control was regressed on the self-report score to examine the specific relation between these two methods of assigning scores to individuals, and the results are depicted in figure 1 for the men. The pattern obtained for the women was almost identical and hence has not been displayed. The broken line represents a simple linear or best fit of the attributed and self-report scores. The unbroken line is the actual observed regression line estimated from the observations for each gender. The regression line (unbroken line) was estimated according to Cleveland's smoothing procedure (35), a nonparametric method that fits the best line to a sequential moving subset of observations, rather than imposing a single linear model on the data. The actual observed trend was found to approximate the "ideal" regression line very closely, for control values in the mid to upper range. At the lower end of the scale, however, the attributed score tended to underestimate the self-report score.

\section{Chronic disease prevalence}

We compared the self-report and attributed scores by examining their respective odds ratios for the prevalence of cross-sectional chronic disease morbidity. Work control was selected for this purpose because of its known association with stress-related chronic disease conditions (9). The latter was defined as a dichotomous variable of having one or more of a subset of illnesses with a plausible stress-related etiology, including cardiovascular disease, digestive system disorders, and back problems. For this analysis both the attributed and self-report work-control scores were divided into quartiles using the same score values for defining each category.

The odds ratios for both the attributed and selfreport scores exhibited a similar stepwise increase in the odds ratios for chronic illness with decreasing 
Table 2. Gender-specific age-adjusted odds ratios and $95 \%$ confidence intervals for the attributed scores of the work organization matrix and self-report scores of the Swedish men $(\mathrm{N}=5312)$ and women $(\mathrm{N}=5069)$ determined for the relation between chronic disease prevalence and work control by quartiles. (OR =odds ratio, $95 \% \mathrm{Cl}=$ confidence interval)

\begin{tabular}{|c|c|c|c|c|c|c|c|c|}
\hline \multirow{3}{*}{$\begin{array}{l}\text { Work-control } \\
\text { quartile }\end{array}$} & \multicolumn{4}{|c|}{ Men } & \multicolumn{4}{|c|}{ Women } \\
\hline & \multicolumn{2}{|c|}{$\begin{array}{l}\text { Work organization } \\
\text { matrix }\end{array}$} & \multicolumn{2}{|c|}{ Self report } & \multicolumn{2}{|c|}{$\begin{array}{l}\text { Work organization } \\
\text { matrix }\end{array}$} & \multicolumn{2}{|c|}{ Self report } \\
\hline & OR & $95 \% \mathrm{Cl}$ & OR & $95 \% \mathrm{Cl}$ & OR & $95 \% \mathrm{Cl}$ & OR & $95 \% \mathrm{Cl}$ \\
\hline $\begin{array}{l}\text { High control } \\
\text { Medium high control } \\
\text { Medium low control } \\
\text { Low control }\end{array}$ & $\begin{array}{l}1.00 \\
1.25 \\
1.50 \\
1.70\end{array}$ & $\begin{array}{l}1.07-1.46 \\
1.27-1.78 \\
1.43-2.03\end{array}$ & $\begin{array}{l}1.00 \\
1.27 \\
1.40 \\
1.76\end{array}$ & $\begin{array}{l}1.08-1.49 \\
1.16-1.71 \\
1.51-2.04\end{array}$ & $\begin{array}{l}1.00 \\
1.18 \\
1.15 \\
1.46\end{array}$ & $\begin{array}{l}1.00-1.40 \\
0.96-1.38 \\
1.21-1.76\end{array}$ & $\begin{array}{l}1.00 \\
1.21 \\
1.06 \\
1.35\end{array}$ & $\begin{array}{l}1.01-1.44 \\
0.87-1.27 \\
1.16-1.57\end{array}$ \\
\hline
\end{tabular}

Table 3. Application of the work organization matrix to a subject's work history to create a lifetime exposure profile.

\begin{tabular}{|c|c|c|c|c|c|c|}
\hline Job title ${ }^{a}$ & $\begin{array}{l}\text { Calendar } \\
\text { year of } \\
\text { exposure }\end{array}$ & $\begin{array}{l}\text { Work } \\
\text { control }\end{array}$ & $\begin{array}{c}\text { Psychological } \\
\text { job } \\
\text { demands }\end{array}$ & $\begin{array}{l}\text { Social } \\
\text { support }\end{array}$ & $\begin{array}{l}\text { Physical } \\
\text { job } \\
\text { demands }\end{array}$ & $\begin{array}{l}\text { Job } \\
\text { hazards }\end{array}$ \\
\hline \multicolumn{7}{|l|}{ Work organization matrix } \\
\hline \multicolumn{7}{|l|}{ Motor vehicle and tram drivers (633) } \\
\hline \multicolumn{7}{|l|}{$25-44$ years of age } \\
\hline $\begin{array}{l}1-5 \text { years of employment } \\
6-19 \text { years of employment } \\
\geq 20 \text { years of employment }\end{array}$ & $\bar{z}$ & $\begin{array}{l}3.88 \\
4.76 \\
4.67\end{array}$ & $\begin{array}{l}4.74 \\
4.91 \\
5.38\end{array}$ & $\begin{array}{l}7.06 \\
6.37 \\
4.76\end{array}$ & $\begin{array}{l}4.39 \\
5.50 \\
6.10\end{array}$ & $\begin{array}{l}3.72 \\
3.92 \\
4.31\end{array}$ \\
\hline \multicolumn{7}{|l|}{$\geq 45$ years of age } \\
\hline $\begin{array}{l}1-5 \text { years of employment } \\
6-19 \text { years of employment } \\
\geq 20 \text { years of employment }\end{array}$ & $\bar{z}$ & $\begin{array}{l}4.72 \\
3.98 \\
3.63\end{array}$ & $\begin{array}{l}4.50 \\
5.19 \\
4.62\end{array}$ & $\begin{array}{l}6.92 \\
7.06 \\
7.08\end{array}$ & $\begin{array}{l}5.08 \\
4.93 \\
4.85\end{array}$ & $\begin{array}{l}2.77 \\
3.37 \\
3.47\end{array}$ \\
\hline \multicolumn{7}{|l|}{ Miners and quarrymen (501) } \\
\hline \multicolumn{7}{|l|}{$25-44$ years of age } \\
\hline $\begin{array}{l}1-5 \text { years of employment } \\
6-19 \text { years of employment } \\
\geq 20 \text { years of employment }\end{array}$ & $\bar{z}$ & $\begin{array}{l}3.50 \\
3.39 \\
4.97\end{array}$ & $\begin{array}{l}3.00 \\
2.86 \\
4.88\end{array}$ & $\begin{array}{l}9.23 \\
8.90 \\
9.53\end{array}$ & $\begin{array}{l}7.59 \\
7.62 \\
7.67\end{array}$ & $\begin{array}{l}8.33 \\
8.09 \\
5.71\end{array}$ \\
\hline \multicolumn{7}{|l|}{$\geq 45$ years of age } \\
\hline $\begin{array}{l}1-5 \text { years of employment } \\
6-19 \text { years of employment } \\
\geq 20 \text { years of employment }\end{array}$ & $\bar{z}$ & $\begin{array}{l}3.93 \\
4.03 \\
4.97\end{array}$ & $\begin{array}{l}5.00 \\
5.83 \\
4.88\end{array}$ & $\begin{array}{l}9.26 \\
8.89 \\
9.53\end{array}$ & $\begin{array}{l}8.07 \\
8.33 \\
7.67\end{array}$ & $\begin{array}{l}8.02 \\
7.59 \\
5.71\end{array}$ \\
\hline \multicolumn{7}{|c|}{ Subject-specific exposure profile by calendar time } \\
\hline \multicolumn{7}{|l|}{ Motor vehicle and tram drivers (633) } \\
\hline \multicolumn{7}{|l|}{$<45$ years of age } \\
\hline $\begin{array}{l}1-5 \text { years of employment } \\
6-19 \text { years of employment }\end{array}$ & $\begin{array}{l}1926-1940 \\
1941-1949\end{array}$ & $\begin{array}{l}3.88 \\
4.76\end{array}$ & $\begin{array}{l}4.74 \\
4.91\end{array}$ & $\begin{array}{l}7.06 \\
6.37\end{array}$ & $\begin{array}{l}4.39 \\
5.50\end{array}$ & $\begin{array}{l}3.72 \\
3.92\end{array}$ \\
\hline \multicolumn{7}{|l|}{ Miners and quarryman (501) } \\
\hline \multicolumn{7}{|l|}{$<45$ years of age } \\
\hline $1-5$ years of employment & $1950-1952$ & 3.50 & 3.00 & 9.23 & 7.59 & 8.33 \\
\hline \multicolumn{7}{|l|}{$\geq 45$ years of age } \\
\hline $\begin{array}{l}1-5 \text { years of employment } \\
6-19 \text { years of employment } \\
\geq 10 \text { years of employment }\end{array}$ & $\begin{array}{l}1953-1955 \\
1956-1969 \\
1970-1974\end{array}$ & $\begin{array}{l}3.94 \\
4.03 \\
4.98\end{array}$ & $\begin{array}{l}5.00 \\
5.83 \\
4.88\end{array}$ & $\begin{array}{l}9.26 \\
8.88 \\
9.52\end{array}$ & $\begin{array}{l}8.07 \\
8.33 \\
7.66\end{array}$ & $\begin{array}{l}8.02 \\
7.59 \\
5.71\end{array}$ \\
\hline
\end{tabular}

a Code of the Nordic version of the International Standard Classification of Occupations in parentheses.

levels of work control for the men (table 2). Among the men the exposure-response trend was more indicative of a stepwise pattern when the attributed score was compared with the self-report score. Among the women no stepwise pattern was observed; rather a similarly elevated odds ratio for both measurement methods was found for the medium high and lowest control quartiles.

\section{Linking the work organization matrix with occupational history}

The application of the work organization matrix to an individual work history is illustrated in table 3 and depicted graphically for work control, psychological job demands, and social support in figure 2. We created an exposure profile by applying the scores of the work organization matrix for motor vehicle oper1ator and miner to the subject's work history. At each stage of his or her work career, age- and durationspecific job scores were assigned to the individual's work history as he or she aged, gained more experience, and changed jobs.

\section{Discussion}

Previous exposure assessment of work organization in the occupational stress field has been based primarily on single point assessment of the respondent's 


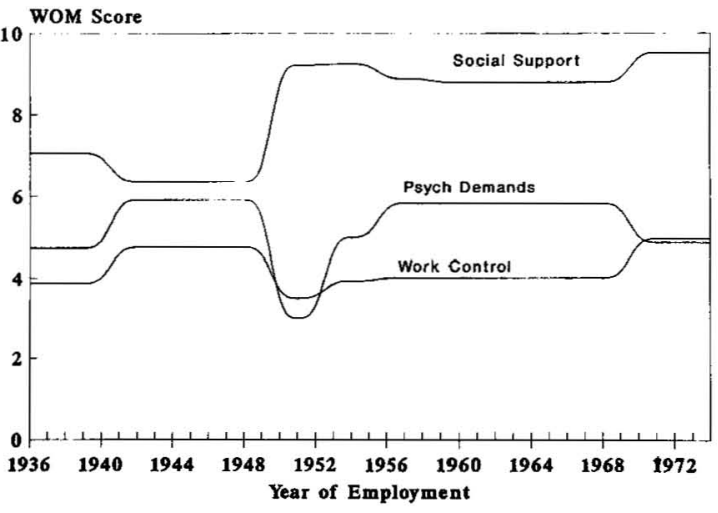

Figure 2. Example of the work organization matrix (WOM) applied to an individual's job history to construct a lifetime exposure profile for psychosocial work organization characteristics. (Psych $=$ psychological)

perception of the work situation at the time of interview. Although the inadequacy of this approach has been pointed out by other investigators $(5,16)$, to date, the methodology has not existed that would permit an examination of the relationship between duration and intensity of work organization exposure and chronic disease risk. The purpose of this paper was to begin to address this major methodological weakness in the psychosocial work-environment field through developing a way to measure the duration and intensity of work exposure over a lifetime. We do not claim that this is the perfect or even the most preferable approach; rather it is an initial attempt to address some of the limitations in the field in order to promote the study of work organization factors with greater methodological rigor.

This paper illustrates the application of a matrix for work organization exposure to self-reported job histories to develop individual exposure profiles. It was found that the elements of the work organization matrix that measure more objective aspects of occupational exposure, such as work control and physical job demands, explained a substantial proportion of the total sample variance. In addition, a similar pattern of association was found for both the work-control scores of the matrix and the individual self-report scores in regard to cross-sectional chronic disease prevalence. The methods outlined in this article, although developed with Swedish data, should be applicable to other national settings in which similar data elements are available, namely, an equivalent, nationally specific matrix in combination with occupational history data.

As mentioned earlier, we are aware that it would be desirable to validate the matrix on other data sets that contain occupational and work environment characteristics. This validation would be useful not only because of the information gained with respect to the potential difficulty of circularity (discussed earlier) but also because this is a new research tool using new approaches to work organization charac- teristics. In this regard, we should note that the work organization matrix has recently been applied in a study of job strain among Swedish men, and a significant association with ambulatory diastolic blood pressure was found (36).

The work organization matrix and other attribution systems are designed to explain the maximal proportion of variance that exists for exposure characteristics at the individual level. This approach works well when the total variation in the work organization variables within the strata defined by the occupational classification groups of the matrix is small relative to the variation that exists between strata. Using covariates to define the strata further helps to minimize the variation that might exist within occupational strata. If a work-exposure characteristic is not associated with the stratification variables that define the job-exposure matrix, the attribution system will be of no value for that work environment trait. For example, the work organization matrix accounted for only a small proportion of individual variance in psychological job demands but for a large proportion of individual variance in work control. This result was probably due to the fact that control is a work characteristic that varies across occupations, whereas psychological demands vary across individuals and work sites within occupations.

Another potential problem with the work organization matrix involves its application to retrospective exposure assignment. When the work organization matrix scores are used to estimate individual exposure characteristics retrospectively, misclassification error may occur because the job has changed at some point in the past. Although the magnitude of the exposure estimates may change, it is less likely that the relative position of one occupation to another will change. Therefore the work organization matrix may still provide valid ordinal-level estimates of past exposure.

Although every job-exposure matrix has its deficiencies, in some instances, attribution systems are superior to individually reported exposure status when an individual's self-report represents a biased assessment of the work environment. Attributed scores are particularly valuable when the daily variation in individual self-reported exposure status is large due to changes in individual perception or actual changes in work practices. In this instance attribution systems can provide a more reliable and more valid estimate of average exposure status than individual self-reports taken at one point in time.

The exposure estimates of attribution systems like the work organization matrix could be improved in several ways. The inherent properties (the reliability and construct validity) of survey-based measurements predetermine the validity of matrix-derived estimates. An improved job-exposure matrix could be constructed based on more rigorous and lengthy questionnaires that focus specifically on objective aspects of work content. Further stratification vari- 
ables could also be added to the matrix to measure aspects which are not captured by the job title and which are strongly associated with exposure of a specific occupation. For example, job control may be strongly associated with position in the organizational hierarchy, size of the work organization, type of ownership, and degree of work participation. To the extent that these factors are important, future surveys may benefit from the collection of additional information that would provide the basis for a development of future job-exposure matrices.

\section{Acknowledgments}

This research is part of collaboration involving the Johns Hopkins School of Hygiene and Public Health, Statistics Sweden, and the Swedish National Institute for Psychosocial Factors and Health. It has been jointly funded by the Swedish Work Environment Fund, project number 88-0416 (grant number 89 0303 ) and the United States National Heart Lung and Blood Institute (grant number HL39633).

The authors gratefully acknowledge the conceptual contributions of $\mathrm{T}$ Theorell, MD, at the Swedish National Institute for Psychosocial Factors and Health, the methodological and programming efforts of P Fredlund, MSc, of Statistics Sweden, the statistical support of T-S Tsou, $\mathrm{PhD}$, of the Johns Hopkins Department of Biostatistics, and the editorial assistance of EM Hall, PhD, Department of Health Policy and Management, The Johns Hopkins University School of Hygiene and Public Health.

\section{References}

1. Gardell B. Psychosocial aspects of industrial production methods. In: Levi L, ed. Society, stress and disease. Oxford: Oxford University Press, 1981:65- 75.

2. Frankenhaeuser M, Gardell B. Overload and underload in working life: outline of a multidisciplinary approach. J Hum Stress 1976;2(3):35-46.

3. Frankenhaeuser M, Levi L, Gardell B. Work stress related to social structures and processes. In: Elliot GR, Eisdorfer C, ed. Research on stress and human health. New York, NY: Springer Publishing Co, 1981:95117.

4. Kahn RL. Work and health. New York, NY: John Wiley \& Sons, 1981

5. House JS, Strecher V, Metzner HL, Robbins C. Occupational stress and health among men and women in the Tecumseh Community Health Study. J Health Soc Behav 1986;27:62-72.

6. Syme SL. Social epidemiology and the work environment. In: Johnson JV, Johansson G, ed. The psychosocial work environment: work organization, democratization and health. Amityville, NY: Baywood Publishing Company, 1991:21-31.

7. Karasek R, Baker D, Marxer F, Ahlbom A, Theorell T. Job decision latitude, job demands and cardiovascular disease: a prospective study of Swedish men. Am J Public Health 1981;71:694—705.

8. Theorell T, Alfredsson L, Knox S, Perski A, Svensson $\mathrm{J}$, Waller $\mathrm{D}$. On the interplay between socioeconomic factors, personality and work environment in the pathogenesis of cardiovascular disease. Scand J Work Environ Health 1984;10:373-80.

9. Karasek RA, Theorell T. Healthy work. New York, NY: Basic Books, 1990.

10. Johansson G, Aronsson G, Lindström BO. Social psychological and neuroendocrine stress reactions in highly mechanized work. Ergonomics 1978;21:58399.

11. Johnson JV, Hall, EM. Job strain, work place social support and cardiovascular disease: a cross-sectional study of a random sample of the Swedish working population. Am J Public Health 1988;78:1336-42.

12. Johnson, JV, Hall, EM, Theorell T. Combined effects of job strain and social isolation on cardiovascular disease morbidity and mortality in a random sample of the Swedish male working population. Scand J Work Environ Health 1989:15:271—9.

13. Kasl SV. Methodologies in stress and health: past difficulties, present dilemmas, future directions. In: Kasl, $\mathrm{SL}$, Cooper CL, ed. Stress and health: issues in research methodology. New York, NY: John Wiley \& Sons, 1987:307-18.

14. Kasl, SV. An epidemiological perspective on the role of control in health. In: Sauter SL, Hurrell JJ, Cooper CL, ed. Job control and worker health. New York, NY: John Wiley \& Sons, 1989:161-89.

15. Marmot MG, Madge N. An epidemiological perspective on stress and health. In: Kasl, SL, Cooper CL, ed. Stress and health: issues in research methodology. New York, NY: John Wiley \& Sons, 1987:3-26.

16. Frese M, Zapf D. Methodological issues in the study of work stress: objective vs subjective measurement of work stress and the question of longitudinal studies. In: Cooper CL, Payne R, ed. Causes, coping and consequences of stress at work. New York, NY: John Wiley \& Sons, 1988:375-411.

17. Baker D. The study of stress at work. Annu Rev Pubic Health 1985;6:367-81.

18. Alfredsson L. Myocardial infarction and environment: use of registers in epidemiology [dissertation]. Stockholm: Karolinska Institute, 1983.

19. Alfredsson L, Karasek R, Theorell T. Myocardial infarction risk and psychosocial work environment: an analysis of the male Swedish working force. Soc Sci Med 1982;16:463-7.

20. Alfredsson L, Spetz C-L, Theorell T. Type of occupation and near-future hospitalization for myocardial infarction and some other diagnosis. Int $J$ Epidemiol $1985 ; 14: 378-88$.

21. Schwartz J, Pieper, C, Karasek, R. A procedure for linking psychosocial job characteristics data to health surveys. Am J Public Health 1988:78;904-9.

22. Karasek R, Theorell T, Schwartz J, Schnall P, Pieper $\mathrm{C}$, Michela J. Job Characteristics in relation to the prevalence of myocardial infarction in the US Health Examination Survey (HES) and the Health and Nutrition Examination Survey (HANES). Am J Public Health 1988;78(8):910-8.

23. Pieper C, LaCroix AZ, Karasek RA. The relation of psychosocial dimensions of work with coronary heart disease risk factors: a meta-analysis of five United States data bases. Am J Epidemiol 1989; 129:483-94.

24. Johnson JV. Control, collectivity and the psychosocial work environment. In: Sauter SL, Hurrell JJ, Cooper CL, ed. Job control and worker health. New York, NY: John Wiley \& Sons, 1989;55-74.

25. Johnson JV, Stewart W, Fredlund P, Hall EM, Theorell T. Psychosocial job exposure matrix: an occupationally aggregated attribution system for work environment exposure characteristics. Stockholm: Karolinska Institute, Department of Stress Research, 1990. (Stress research reports; 221.)

26. Checkoway H, Pearce N, Crawford-Brown, DJ. Re- 
search methods in occupational epidemiology. New York, NY: Oxford University Press, 1989.

27. Hoar SK, Morrison AS, Cole P, Silverman DT. An occupational and exposure linkage system for the study of occupational carcinogeneses. J Occup Med 1980; 22:722-6.

28. Corn M, Esmen, NA. Workplace exposure zones for classification of employee exposures to physical and chemical agents. Am Ind Hyg Assoc J 1979;40:4757.

29. Hall EM. Double exposure: the combined impact of the home and work environments on psychosomatic strain in Swedish women and men. Int J Health Serv $1992 ; 22: 239-60$.

30. Hall EM. Gender, work control, and stress: a theoretical discussion and an empirical test. Int J Health Serv 1989; $19: 725-45$.

31. Johnson JV. The impact of workplace social support and work control upon cardiovascular disease in Sweden. Stockholm: University of Stockholm, 1986. (Environmental and organizational psychology research reports; 1.)

32. Swedish Central Bureau of Statistics (SCB). FOB75: Systematisk yrkescod. Stockholm, Sweden: SCB, 1975.

33. Hall, EM: Women's work: an inquiry into the health effects of invisible and visible labor [dissertation]. Stockholm: Karolinska Institute, Department of Stress Research, 1990.

34. SAS Institute. SAS procedures guide, release 6.03 edition. Cary, NC: SAS Institute, 1988.

35. Cleveland WS. Robust locally weighted regression and smoothing scatterplots. J Am Stat Assoc 1979;74: 829-36.

36. Theorell T, de Faire U, Johnson JV, Hall E, Perski A, Stewart W. Job strain and ambulatory blood pressure profiles. Scand J Work Environ Health 1991;17:3805 .

Received for publication:13 February 1992 